\title{
14. THE CONSTRUCTIONAL AND DEFORMATIONAL HISTORY OF THE IGNEOUS BASEMENT PENETRATED AT SITE 786 ${ }^{1}$
}

\author{
Y. Lagabrielle, ${ }^{2}$ J.-P. Sizun, ${ }^{2}$ and R. J. Arculus ${ }^{3}$
}

\begin{abstract}
The results of a petrographic analysis of clastic facies recovered from Hole 786B are presented along with a summary of the structural data obtained from Holes $786 \mathrm{~A}$ and $786 \mathrm{~B}$. These data are used to reconstruct the general lithostratigraphy and structure of the boninite and related rock suite which constitutes the Eocene-Oligocene basement of the forearc basement high of the Bonin arc area. Evidence has been sought that can provide insight into the depositional environments (deep water, shallow water, or subaerial conditions) of most of the volcaniclastic intervals drilled at Site 786.

Sedimentary breccias recovered from the basal part of Hole 786B are associated with pillow lavas. These breccias consist entirely of in-situ-derived hyaloclastite and pillow fragments, probably representing talus deposits that were reworked by debris flow. The components of epiclastic breccias and sandstones recovered from shallower levels in Hole 786B are derived from more diverse sources, including pillow lavas, altered andesite, tuffs, and pumice. Fragments of volcanic products emplaced in subaerial or shallow-water environments also become more abundant.

Analysis of selected pyroclastic facies from the cores revealed that products generated by explosive volcanism increase in abundance in the uppermost part of Hole 786B, from 550 to 350 meters below seafloor. This indicates that these products have been emplaced above the "pressure compensation level," that is, at a shallow level (less than $500 \mathrm{~m}$ depth), and that the volcanic edifice must have emerged above sea level, at least locally and possibly more than once during the middle to late Eocene. On the basis of these data, a schematic reconstruction of the basement structure and stratigraphy, and a possible constructional history of the volcanic edifice, is presented.

The main Eocene volcanic and plutonic constructional stage of the present forearc basement high was followed by a period of active subsidence. During this subsidence stage, the basement reached its present-day depth (more than $3000 \mathrm{~m}$ ). Subsidence was probably not a steady-state process but took place presumably during several separate episodes. According to the local sedimentation rate curves calculated for Site 786, and more generally to the evolution of the northeastern margin of the Philippine Sea Plate, these periods are likely to have been at the end of the Eocene, early Oligocene, early to middle Miocene, and at the Miocene to Pliocene boundary.
\end{abstract}

\section{INTRODUCTION}

The basement drilled at Site 786 on the forearc basement high (FBH) of the Bonin arc (Fig. 1) is characterized by the presence of numerous volcaniclastic intervals of various types and origin (epiclastic, pyroclastic, and hydroclastic) interbedded with massive or pillowed lavas of boninitic and bronzite andesite affinity. Numerous dikes of these rock types, together with rhyolite and various types of andesite and dacite, are also present, especially in the lower part of the section (see Arculus et al., this volume). In addition, considerable evidence of deformation postdating the igneous activity, such as normal faulting and tilting, have been reported in the core descriptions (Shipboard Scientific Party, 1990).

The variety of clastic and nonclastic volcanic facies observed in the forearc basement of Hole 786B indicates a rather complex history of volcanic construction and related sedimentation in a spectrum of environments. We interpret the structural data obtained from both Holes $786 \mathrm{~A}$ and $786 \mathrm{~B}$ as showing that the igneous constructional period was followed by periods of active faulting (Fig. 2). In this contr'bution, we attempt to define the main stages of this igneous and post-igneous history and thus to provide some new constraints relevant to the evolution of the Izu-Bonin forearc from the Eocene to the present.

Based on the lithostratigraphy, cross-cutting relations, and $\mathrm{K}-\mathrm{Ar}$ dating (Arculus et al., this volume; Mitchell et al., this volume), the

'Fryer, P., Pearce, J. A., Stokking, L. B., et al., 1992. Proc. ODP, Sci. Results, 125: College Station, TX (Ocean Drilling Program).

2URA CNRS 1278 and G.D.R. (Genèse et Evolution des Domaines Océaniques), 6 Avenue le Gorgeu, 29287 Brest Cédex. France.

${ }^{3}$ Department of Geology and Geophysics, University of New England, Armidale, N.S.W. 2351, Australia. igneous constructional history of the FBH at Site 786 can be summarized as follows: (1) a pillow lava-feeder dike complex of low-Ca boninites and low-Ca bronzite andesites forms; (2) flows and breccias of intermediate-Ca boninite and intermediate-Ca bronzite andesite, andesite, dacite, and rhyolite overlie the pillow-dike complex; dikes and sills of these compositions also cut the pillow-dike complex; and (3) high-Ca and intermediate- $\mathrm{Ca}$ boninite dikes cut this basement. Stages 1 and 2 are about 41 Ma whereas stage 3 occurred at about 35 $\mathrm{Ma}$. It is possible that a further intrusive episode of high-Ca boninite occurred at about $17 \mathrm{Ma}$.

Rare, poorly to moderately preserved calcareous nannofossil assemblages, indicating a middle to late Eocene age, have been found in volcanogenic sedimentary rocks from Sections 125-786B-22R-1, $-27 R-2,-40 R-1,-41 R-3,-49 R-1,-51 R-2$ and $-56 R-C C$. Samples from Sections 125-786B-61R-6 and -63R-1 contain nannofossil assemblages of early Eocene age (Shipboard Scientific Party, 1990). In addition to these age assignments, the occurrence of marine nannofossils is, of course, a clear indication that a considerable portion of the volcanic, hypabyssal, and volcaniclastic products recovered from Core 125-786B-22R (360 meters below sea floor [mbsf]) to the bottom of Hole 786B were emplaced under submarine conditions. Unfortunately, the presence of calcareous nannofossils in such volcanogenic sediments does not indicate water depth at the time of deposition, and one cannot even discriminate between shallow or deep-water environments. Moreover, periods of subaerial deposition may alternate with periods of slight subsidence and submarine deposition even though the absence of fossils cannot necessarily be correlated with subaerial deposition. Additional information is needed in order to determine unequivocally the depositional environment of the clastic intervals drilled at Site 786. Fortunately, the features of the clastic volcanic facies help define the main character of the depositional environments. 


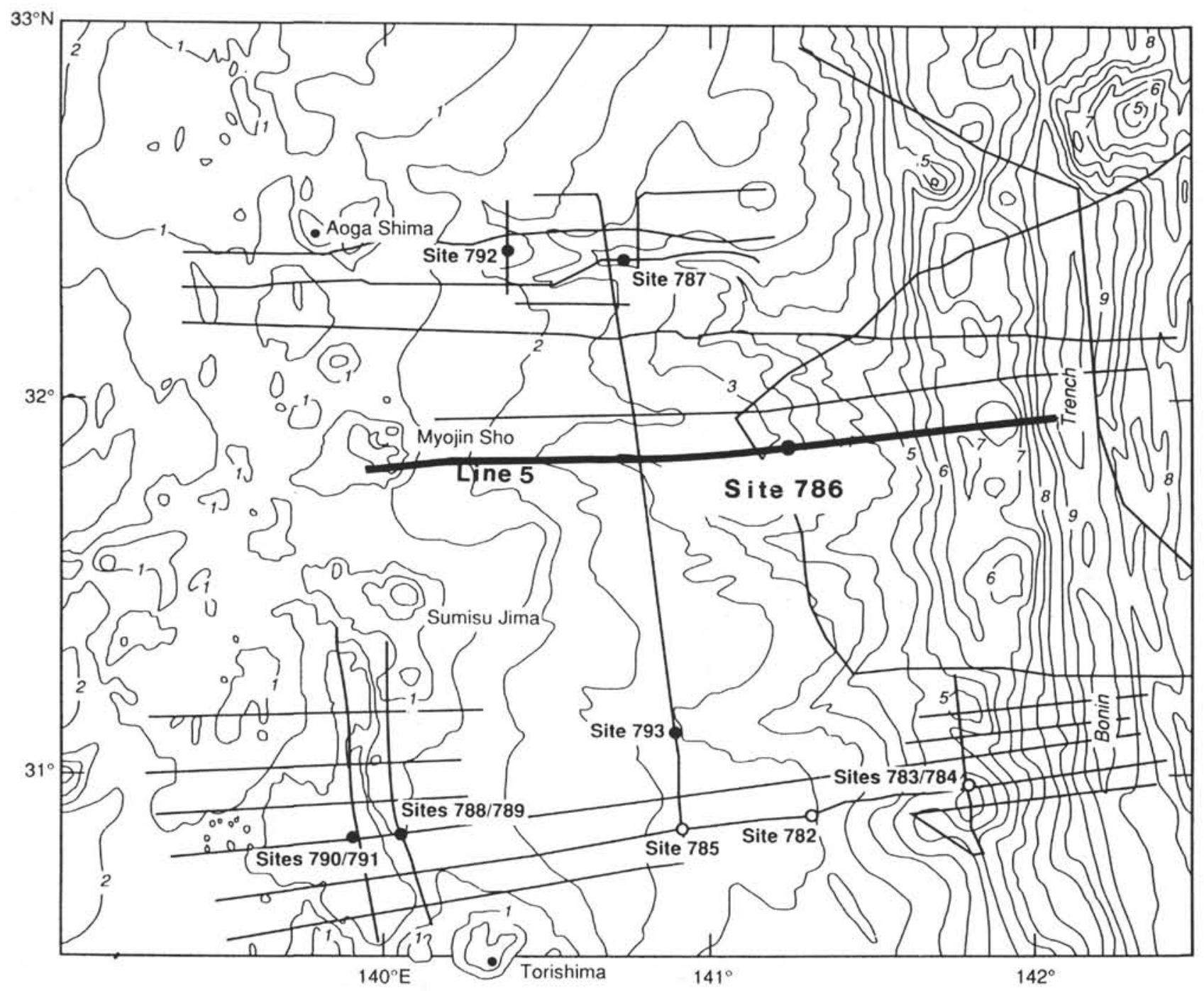

Figure 1. Bathymetric map (in kilometers) of the Izu-Bonin arc and forearc areas. Location of ODP sites drilled during Legs 125 and 126 and location of multichannel seismic lines run by B. Taylor. Line 5 is indicated in bold.

In this preliminary study, we present the results of petrographic examination supported by X-ray diffraction (XRD) analysis of 43 selected samples of various volcaniclastic intervals from Hole 786B. First, we list some of the main characteristics of the rocks. Second, we discuss the primary criteria by which an assessment of the environment of deposition of the volcanic and/or volcanic-derived products can be made: deep to shallow-water conditions or under subaerial conditions. Additional information obtained from a structural analysis of the cores is also presented. These data, some of which have been presented previously (Shipboard Scientific Party, 1990), collectively provide crucial information relative to the tectonic history of the basement drilled at Site 786. The names used to describe the various igneous lithologies are defined by Arculus et al. (this volume).

\section{VOLCANICLASTIC ROCKS OF HOLE 786B}

The 43 selected samples come from Sections 125-786B-3R-1, $-21 \mathrm{R}-1,-22 \mathrm{R}-1,-22 \mathrm{R}-2,-22 \mathrm{R}-3,-27 \mathrm{R}-1,-31 \mathrm{R}-2,-33 \mathrm{R}-1,-34 \mathrm{R}-1$, $-37 R-2,-39 R-2,-40 R-1,-41 R-2,-41 R-3,-43 R-1,-48 R-1,-49 R-2$, $-49 R-3,-54 R-3,-56 R-2,-57 R-5,-57 R-6,-60 R-3,-60 R-5,-62 R-3$, $-63 R-1$, and $-72 R-2$. Clastic fabrics of various types (cataclastic, hydroclastic, pyroclastic, or epiclastic) are apparent in all of these samples. Sampling intervals and exact location of the samples within the drilled column are reported in Figure 2.
The following sediment types can be recognized from the bottom to the top of Hole 786B.

\section{Hydrothermal, Hydraulic Breccias}

Sample $125-786 \mathrm{~B}-72 \mathrm{R}-2,111-112 \mathrm{~cm}$, is a highly chloritized, low- $\mathrm{Ca}$ bronzite andesite breccia with abundant pyrite grains. No significant displacement between the rock fragments is visible, and brecciation is probably related to a fluid over-pressure (hydraulic fracturing). Clear evidence of hydrothermal circulation has been reported for the lower part of the hole; they include extensive alteration to albite, chlorite, epidote, and quartz with much brecciation and development of pyrite and calcite in veins, fractures, and pods primarily developed in dikes (Shipboard Scientific Party, 1990). The occurrence of such breccias associated with numerous dikes confirm that the lower part of the hole consists of an igneous facies usually encountered in the deeper parts of volcanic edifices.

\section{Tectonic Breccias}

Samples 125-786B-63R-1, 129-133 cm; 125-786B-63R-1, 68-74 $\mathrm{cm}$; and 125-786B-63R-1, 62-68 cm, are from a major fault zone that cross-cuts low-Ca boninite and low-Ca bronzite andesite lavas at $750 \mathrm{mbsf}$. The deformed zone corresponds to the lower part of Section 
125-786B-62R-3, the entire Section 125-786B-63R-1, and some of Section 125-786B-63R-2. The smallest pieces within these sections are centimeter-sized fragments, showing slickensides, and probably representing debris from fault gouge. The longest piece (9A and 9B) is $44 \mathrm{~cm}$ long, at interval 125-786B-63R-1, 50-94 cm. The top of this piece is a volcanic breccia, probably of cataclastic origin. The clasts are up to $3-5 \mathrm{~cm}$ wide and do not show any clear preferred orientation. In places, they are cross-cut by millimeter-thick shear zones.

A major shear zone defined by a well-developed tectonic foliation, with an apparent dip of $70^{\circ}$, is present in interval 125-786B-63R-1, $66-94 \mathrm{~cm}$. The clasts within the shear zone are no more than a few millimeters wide, and the central part of the deformed zone resembles a mylonite. Thin-section analysis of Sample 125-786B-63R-1, 68-74 $\mathrm{cm}$, reveals that the deformed rock shows a well-developed schistosity ( $S$ planes) and discontinuous shear planes ( $C$ planes) dipping at $70^{\circ}$ (Fig. 3). Relationships between $C$ and $S$ planes, especially the bending of $S$ planes as $C$ planes are approached, indicate a normal sense of shear along the fault zone (Berth et al., 1979). Similar senses of shear were deduced from other fault zones observed in core during onboard structural studies (Shipboard Scientific Party, 1990).

\section{Hematite-rich Hyaloclastite Sandstone and Pillow Breccias}

Green hyaloclastic sandstones are associated with pillows and pillow breccias in Cores $125-786 \mathrm{~B}-62 \mathrm{R}$ to $-54 \mathrm{R}$. The presence of pillows, brecciated pillows, and hyaloclastite sandstones confirm that this part of the succession was formed in a subaqueous environment, probably at substantial depth. However, the development of pillows and lack of pyroclastic deposits cannot be systematically correlated with a deep-sea environment.

The samples studied comprise pillow and hyaloclastite breccias and sandstones. They are composed of fresh glassy fragments from cores and rims of low-Ca boninite and low-Ca bronzite andesite pillows, together with palagonitized and argillized glass fragments, and isolated mineral debris. Some of the samples (125-786B-62R-3, $121-124 \mathrm{~cm} ;-62 \mathrm{R}-3,87-91 \mathrm{~cm} ;-60 \mathrm{R}-5,65-68 \mathrm{~cm}$, and $-57 \mathrm{R}-5$, 66-68 cm) show contorted red layers composed of hematite (confirmed by XRD analysis). Locally, hematite-rich layers show cauliflower structures, suggesting deposition by precipitation from circulating, iron-rich solutions. Iron enrichment probably results from hydrothermal circulation linked to the igneous activity. In Sample 125-786B-60R-5, 65-68 cm, wairakite and saponite have been identified by XRD analysis.

Bedding is visible in a 2-cm-thick red layer of Sample 125-786B$62 \mathrm{R}-3,121-124 \mathrm{~cm}$. Thin-section observation and XRD analysis shows that this layer is composed of very fine-grained hematite, quartz, and pyrite particles, indicating deposition by gravity or bottom currents.

Cores 125-786B-60R and -61R (Sections 1 to 4) are almost totally composed of oligomict volcanic (low-Ca boninite and low-Ca bronzite andesite) glass-rich sandstones and associated breccias. Finegrained material is dominant. Pure sandstone layers without any centimeter-sized clasts range up to $1 \mathrm{~m}$ in thickness. However, angular clasts are scattered locally within the sandstones. Some of the clasts

Figure 2. Synthetic table of the main paleontological, structural, and petrological results, Hole 786B. Paleontological ages are based on the occurrence of calcareous nannofossils in some sedimentary intervals. Tectonic features include normal shear zone (NSZ), fracturing and veining (FV), conjugate faults (CF), subhorizontal striation (SS), normal fault (NF), and hydrothermal breccias (HB). Apparent dips of bedding and flow-banding (locally flattened vesicles alignment) are in degrees. Black circles refer to samples (one circle per sample). Simplified lithology: $\mathrm{HB}=$ hydrothermal breccias; $\mathrm{H}=$ hyaloclastite and pillow breccia and/or sandstone; $\mathrm{E}=$ epiclastic breccia and/or sandstone; $\mathrm{P}=$ pyroclastic breccia and/or sandstone; $\mathrm{A}=$ autoclastic breccia; $\mathrm{F}$ $=$ more or less brecciated flow.

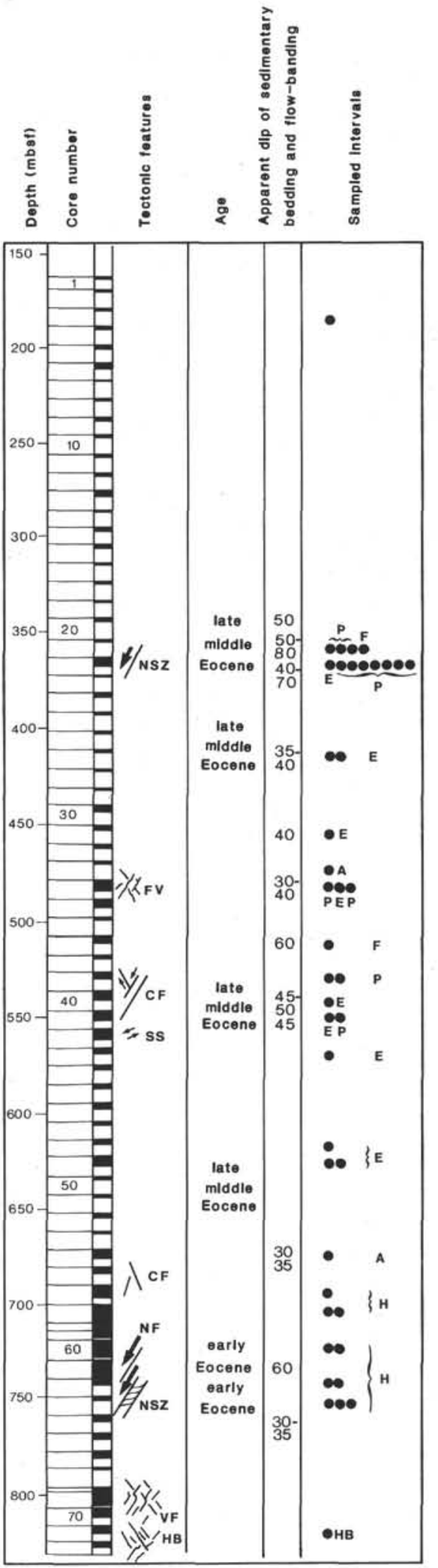



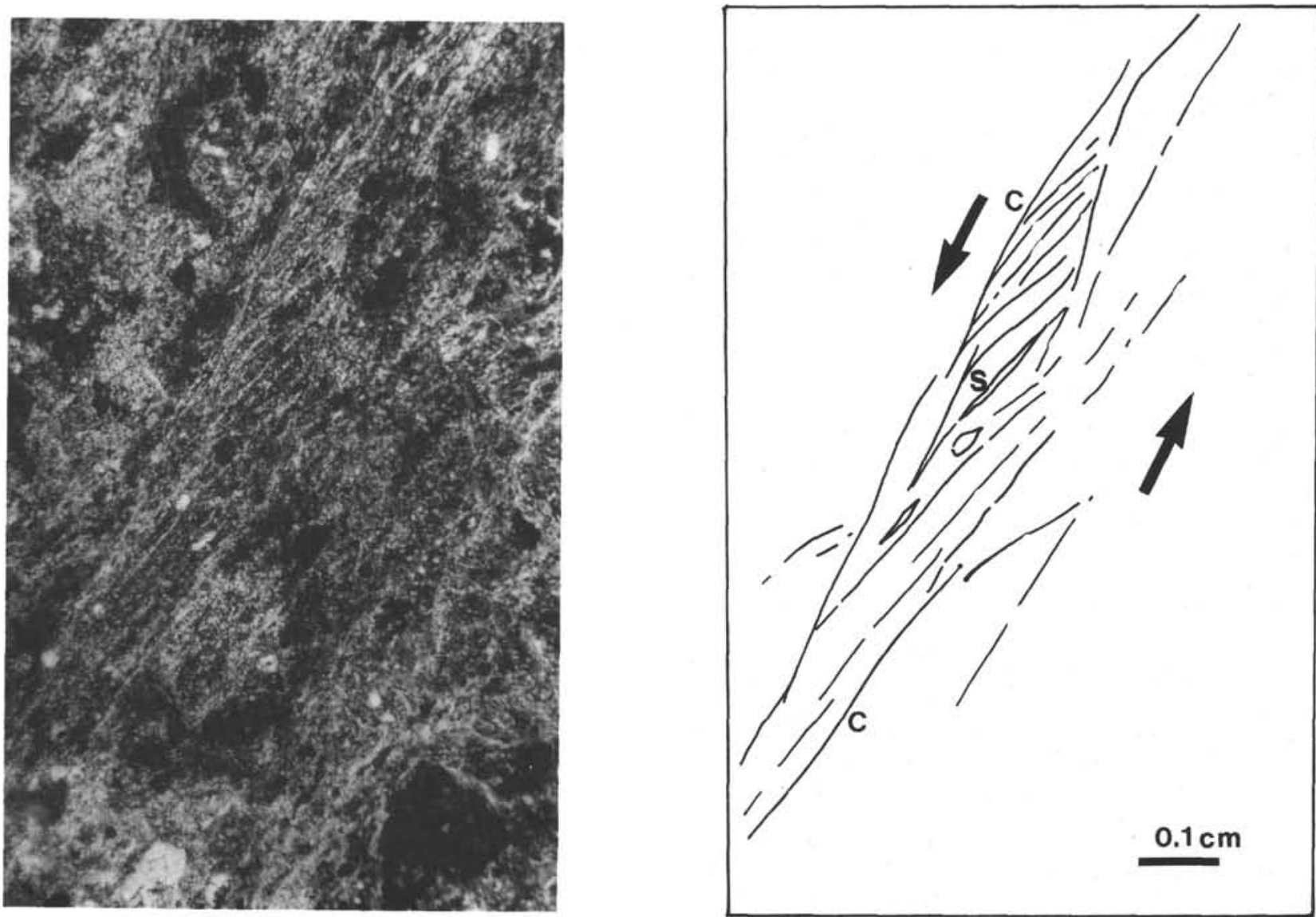

Figure 3. $C$ - and $S$-plane relationships, indicating a normal sense of motion in a decimeter-thick shear zone that cross-cuts pillow breccias and sandstones in interval $125-786 \mathrm{~B}-63 \mathrm{R}-1,68-74 \mathrm{~cm}$.

exhibit banding and chilled zones, indicating that they are fragments of pillow margins.

Thin sections of Samples 125-786B-60R-3, 51-56 cm, and 125786B-60R-5, 65-68 cm, show that the rock is composed mostly of glassy volcanic fragments. The glass is highly altered to montmorillonite, and pyroxene phenocrysts are mostly replaced by clays and calcite. Some centimeter-sized glassy fragments have numerous vesicles. The monogenic composition suggests that this clastic interval represents fragmented material reworked from a proximal source, probably talus scree deposits, and emplaced rapidly by gravity currents in response to basement movements. Given the significant thickness $(12 \mathrm{~m})$ developed, this boninitic-bronzite andesiticsandstone layer can be interpreted as the sedimentary product of an important event such as faulting that affected the volcanic pile during or immediately after lava emplacement. Comparable thick boniniteandesite-dacite sandstone horizons are developed on the island of Chichijima, intercalated with pillow lava and hyaloclastite-rich horizons (Umino, 1985, 1986).

Thin sections from Samples 125-786B-57R-5, 66-68 cm; -57R-6, $66-69 \mathrm{~cm}$; and $-56 \mathrm{R}-2,71-75 \mathrm{~cm}$, confirm that foreign clasts are absent within the breccias and sandstones associated with the pillow lavas of Cores $125-786 \mathrm{~B}-62 \mathrm{R}$ to $-54 \mathrm{R}$, and that the fragmental material originated exclusively from proximal volcanic products, mostly rims and cores of pillows. In Sample 125-786B-54R-3, 116$120 \mathrm{~cm}$, the volcanic clasts that are up to $2 \mathrm{~cm}$ in diameter show poorly defined outlines. In thin section, partially altered glass appears to form the matrix of this breccia. The clasts are angular, poorly sorted, matrix-supported, and show variable dark gray to gray colors. Fragmentation probably occurred during emplacement of lava.

\section{Polymict Epiclastic Breccias, Microbreccias, and Sandstones}

The drilled section is characterized by the presence of two main sedimentary, polymict volcanic breccia intervals, each about $100 \mathrm{~m}$ thick (Core 125-786B-57R to Section 125-786B-44R-2, $10 \mathrm{~cm}$, and from Cores 125-786B-17R to -7R). Other minor polymict breccia and sandstone intervals are found between these two main breccia intervals. Samples from most of these thin beds have also been studied.

The lowermost of these intervals consists of two sequences of matrix-supported, polymict breccias: the lower sequence (Sections $125-786 \mathrm{~B}-57 \mathrm{R}-1,0 \mathrm{~cm}$, to $-51 \mathrm{R}-1,0 \mathrm{~cm}$ ) is dominated by subangular to rounded clasts of variably altered, intermediate-Ca boninite, low$\mathrm{Ca}$ boninite, and intermediate-Ca bronzite andesite, and the upper sequence $(125-786 \mathrm{~B}-51 \mathrm{R}-1,0 \mathrm{~cm}$, to $-44 \mathrm{R}-2,10 \mathrm{~cm})$ by similarly altered clasts, dominantly of intermediate-Ca bronzite andesite, but also rarer andesite clasts. This breccia interval overlies the pillows and hyaloclastite-pillow breccias described in the previous section. No plutonic rocks have been found in this lowest interval, whereas microgabbroic fragments have been reported from the upper interval.

The clasts in these breccias range in size up to a few centimeters in diameter. Some subangular clasts, gray to dark gray in color, were described as tuff or welded ash flow fragments (Shipboard Scientific Party, 1990). Rounded clasts are yellowish to red, strongly altered volcanic rocks, mainly andesites. Many subrounded clasts have brown-red to gray rims, suggesting weathering rims.

Thin-section observations of selected fine-grained samples from this interval confirm the polymict character of the breccias. Millimeter-sized clasts in Samples 125-786B-49R-3, 56-60 cm; -49R-2, $70-74 \mathrm{~cm}$; and $-48 \mathrm{R}-1,68-72 \mathrm{~cm}$, show variable shapes and altera- 
tion profiles. Subangular fragments are more or less palagonitized glassy volcanic rocks with fresh orthopyroxene and clinopyroxene phenocrysts; rounded clasts are strongly altered, two-pyroxene-bearing microlitic andesite. Other clasts are vesicular, microlitic volcanic rocks exhibiting flow-banding. The glassy groundmass of these rocks show alteration zoning with yellowish areas of palagonite.

Although tuffs and welded ash flow debris have been reported from the core descriptions (Shipboard Scientific Party, 1990), these rock types have not been clearly recognized in the studied thin sections. The very fine-grained hematite-bearing matrix of the breccias is dominated by pyroxene fragments. In Sample 125-786B-49R$2,70-74 \mathrm{~cm}$, voids between the main fragments appear to have been filled by secondary minerals (zeolite?). Some andesitic clasts are characterized by pervasive alteration with development of hematite and $\mathrm{Fe}$-hydroxides. Other clasts show only alteration rims whereas most of the glassy angular fragments are devoid of weathering rims.

These observations emphasize the polymict character of these detrital rocks and indicate that the fragmental material originated from at least two different sources: a proximal source of angular clasts of glassy volcanic rocks, either weakly altered subaqueous pillowed lava flows or fragmented blocks of hyaloclastite, and a more distal source of strongly altered, reddened andesites. It is possible that this last type of clast originated from fragmented, subaerially weathered flows. We suggest that this breccia interval represents the record of an important tectonic event that affected a significant part of the edifice, leading to the reworking of both proximal, deep submarine pillowed lavas and distal, strongly altered, terrestrial lavas. Again, an analogy can be found in the uppermost volcanic formation (Mikazukiyama) on the island of Chichijima, which also contains fragments from these two types of source (Umino, 1985, 1986).

Between the two main breccia intervals, numerous thin polymict detrital layers are interbedded with the volcanic products: (1) at the bottom of Section 125-786B-43R-1; (2) in interval 125-786B-41R-3, $15-35 \mathrm{~cm}$; (3) at the top of Section 125-786B-40R-1; (4) in interval 125-786B-34R-1, 65-75 cm; (5) in interval 125-786B-31R-2, 10-20 $\mathrm{cm}$; (6) at the bottom of Section 125-786B-27R-1; and (7) at the bottom of Section 125-786B-22R-3. Most of these layers are characterized by an assemblage of clasts of various origins. The presence of such detrital beds demonstrates that periods of relatively active sedimentation occurred between periods of volcanism. These beds may reflect long gaps in the volcanic activity without significant increase in the tectonic activity, but they may also represent the sedimentary record of periods of important tectonic rejuvenation.

Sample 125-786B-43R-1, 125-129 cm, is a polymict mafic microbreccia composed of glassy volcanic fragments, altered microlitic volcanic rocks, and broken isolated crystals set in a very fine-grained, reddened matrix, although no hematite could be detected with XRD analysis. Calcite is found in veins infilling some of the voids between the fragments.

Sample 125-786B-41R-3, 20-23 cm, is a coarse, graded-bedded sandstone composed of angular fragments (one millimeter or less in width) of partly devitrified, laminated glass (pumice fragments) and of subrounded to rounded, brown to red-brown clasts of altered, hematitized, clinopyroxene-bearing intermediate-Ca bronzite andesite. Less abundant components that form the groundmass are isolated minerals, strongly altered microlitic bronzite andesite debris, and altered glass fragments.

Millimeter, subangular clasts from the polymict microbreccia at interval $125-786 \mathrm{~B}-40 \mathrm{R}-1,14-18 \mathrm{~cm}$, are characterized by relatively thick red rims, suggesting either hydrothermal alteration or more probably weathering under subaerial conditions prior to their incorporation within the breccia. The dominant clasts are fragments of mafic rocks with either microlitic or glassy vesicular texture, most likely derived from the rims of pillows. Other minor clasts exhibit a lamination caused by alignment of flattened vesicles or show eutaxitic structure. These latter clasts may represent fragments of welded air-fall or ash-flows tuffs (Sheridan, 1979; Sparks and Wright, 1979) emplaced either in subaerial or very shallow water environments. Therefore, this microbreccia clearly shows a mixing of volcanic products derived from different sources.

Sample 125-786B-34R-1, 64-68 cm, belongs to a thin interval ( 30 $\mathrm{cm}$ maximum thickness) of hematite-bearing volcanic sandstones in contact with autoclastic, flow-banded andesite breccias. The rock exhibits normally graded bedding. It consists of crystal fragments of orthopyroxene, plagioclase, and minor clinopyroxene, and lithic fragments of laminated or contorted glass (pumice fragments) and altered volcanic rocks. All the elements show iron-rich reddened rims and the whole rock is characterized by a red color typical of hematite (confirmed by XRD analysis). The occurrence of pumice fragments and strong hematinic alteration suggest the influence of terrestrial sources. This rock could have been derived from the reworking of volcanic sands formed in high-energy environments, such as those characteristic of beaches and rivers, which have suffered subsequent alteration under subaerial conditions. However, hematite enrichment may also be a consequence of hydrothermal circulation.

Sample 125-786B-31R-2, 15-18 cm, is a monogenic breccia with subangular, 2- to 3-cm-wide fragments of reddened bronzite andesite enclosed in a matrix of smaller lithic clasts of the same type, and abundant broken, but not rounded, crystal fragments of plagioclase and pyroxene. These crystal fragments and calcite form almost the totality of the matrix. This breccia shows an oligomictic character indicating poor transportation and can be interpreted as the result of in-situ epiclastic fragmentation of medium-Ca bronzite andesite flows under marine conditions allowing calcite deposition.

Samples 125-786B-27R-1, 145-148 cm, and 125-786B-27R-1, $112-115 \mathrm{~cm}$, belong to the most spectacular volcaniclastic sedimentary interval encountered at Site 786. This interval, about $20 \mathrm{~cm}$ thick, is found at the bottom of Section 125-786B-27R-1. It underlies an oligomictic rhyolite breccia and vesicular andesite lava flows, and consists of green, yellowish coarse to fine-grained volcanic

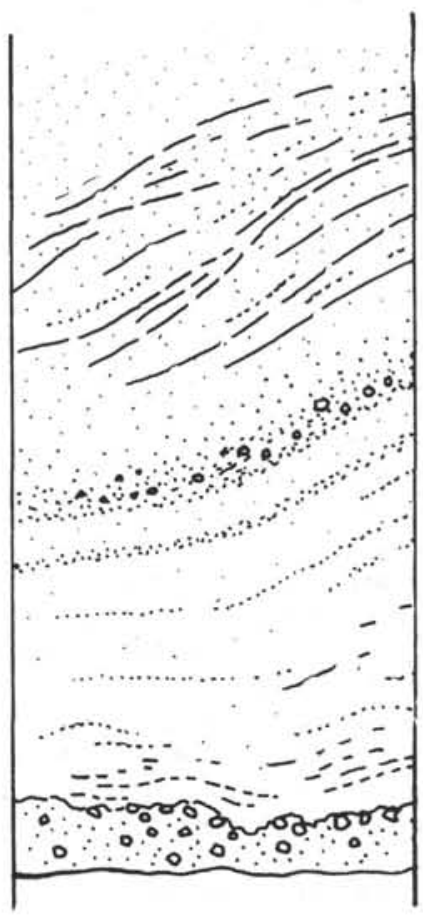

129

$149 \mathrm{~cm}$

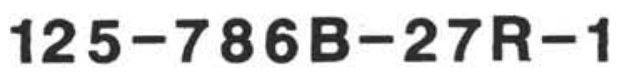

Figure 4. Sedimentary structures, including gradedbedding, wavy, and crossed laminations, in a thin volcanic sandstone interval of Section 125-786B-27R-1. 
sandstones showing very clear bedding and sedimentary structures including: graded-bedding, high-angle cross-bedding and wavy lamination (Fig. 4). These structures suggest deposition by traction currents rather than by gravity currents. Thin-section studies reveal that the sandstones are composed of dominant, very altered (with montmorillonite) lithic, vitric, and crystal fragments. Hematite grains are abundant in some layers. Alteration in places prevents identification of the specific primary clast characteristics. The material reworked in these sandstones probably suffered a rather long evolution, involving fragmentation, alteration, transportation, and deposition in a high-energy environment such as a near-shoreline environment.

Sample $125-786 \mathrm{~B}-22 \mathrm{R}-3,112-115 \mathrm{~cm}$, is a polymict breccia containing poorly sorted fragments of various colors (green, white, red) and shapes enclosed in a red, fine-grained matrix. Clasts include angular fragments of laminated tuffs (probably welded tuffs) and more rounded debris of altered (oxidized) andesite (and possibly boninite). The fine-grained matrix is a volcanic sandstone with glass fragments and abundant crystal debris. This breccia interval is only $15 \mathrm{~cm}$ thick; it is overlain by bedded volcanic sandstones $10 \mathrm{~cm}$ thick. Both breccia and sandstone are overlain by a complex sequence of welded tuffs, glassy andesitic flows, and related pyroclastic rocks found in Cores 125-786B-21R and -22R.

The thickest breccia interval drilled in the basement at Site 786 is present in Cores 125-786B-17R to -7R (about 320 to $220 \mathrm{mbsf}$ ). It consists of a matrix-supported polymict breccia dominated by andesite clasts in the uppermost and lowermost thirds (Sections 125786B-7R-1, $0 \mathrm{~cm}$, to $-10 \mathrm{R}-1,0 \mathrm{~cm}$, and $125-786 \mathrm{~B}-14 \mathrm{R}-1,8 \mathrm{~cm}$, to 125-786B-17R-1, $100 \mathrm{~cm}$, respectively), and intermediate-Ca boninite and intermediate-Ca bronzite andesite in between these intervals. Less abundant clasts are gray pumice fragments. Some rare pieces of microgabbro, possibly of cumulate origin, have also been observed. The degree of pervasive alteration of the clasts is highly variable. Hematinic staining is visible in some samples. Vesicles in different clasts have different orientations and no vesicles are present in the fine-grained matrix. Variety in the composition of the clasts and degree of alteration, as well as the lack of magmatic texture of the matrix, are consistent with a sedimentary origin for the breccia. This unit is similar to the lower main breccia interval, present in Cores $125-786 \mathrm{~B}-57 \mathrm{R}$ to $-44 \mathrm{R}$. It was probably emplaced by gravity currents and is thought to represent the sedimentary record of a second major tectonic event that affected the volcanic basement.

In conclusion, analysis of sedimentary volcaniclastic intervals of Hole 786B shows a clear evolution from the bottom to the top of the Hole. The lowest samples are characterized by the abundance of glassy, palagonitized fragments mostly derived from pillow lavas. In contrast, samples from the main basal breccia interval (700-585 mbsf) and from minor intervals between the two main breccia units are characterized by increasing numbers of fragments of oxidized, altered lavas; they also contain a higher proportion of pumice clasts. This evolution is consistent with the general lithostratigraphy deduced from the magmatic products, showing the development of pillowed lavas at the base (between 750 and $680 \mathrm{mbsf}$ ) and occurrence of nonpillowed lavas (mostly andesite and dacite) and rhyolitic tuffs and flows in the uppermost section ( 500 to $350 \mathrm{mbsf}$ ). The main upper breccia interval (320-220 mbsf) contains various clasts that also indicate diverse sources, including subaerial (pumice) and subaqueous rocks (pillows). The two main polymict breccia units represent major changes in the constructional history of the volcanic edifice, probably in relation to tectonic events that occurred during the early stages of the evolution of the Bonin arc.

\section{Pyroclastic Breccias and Related Tuffs}

Most of the samples included in this lithological group were selected on board because they show rather controversial textures, some of which are typical of sedimentary deposits. Especially significant are samples from Cores $125-786 \mathrm{~B}-22 \mathrm{R}$ and $-21 \mathrm{R}$ that show brecciation, crosslamination, syndepositional folding, and faulting. We now conclude that these features are not related to "cold" sedimentary events but to "hot" explosive fragmentation, transportation, and deposition.

Pyroclastic rocks are fragmented rocks generated by explosive ejection taking place in both subaerial or submarine environments (Honnorez and Kirst, 1975; Sheridan, 1979; Fisher and Schmincke, 1984; Cas and Wright, 1987). The explosive or effusive character of underwater volcanic eruptions is a function of depth (pressure) of the water column, the composition of the magma (amount of volatiles), and the extent of interaction between the magma and water (see synthesis in Fisher, 1984; Yamada, 1984; Cas and Wright, 1987). The depth at which pyroclastic fragmentation may occur, caused by gas-separation and expansion of volatiles within the magma, is called the pressure compensation level (PCL) (Fisher, 1984). It is generally less than $500 \mathrm{~m}$ for most basaltic magmas but may be $500-1000 \mathrm{~m}$ for more explosive, intrinsically volatile-rich alkali magmas and possibly those characteristic of Site 786 (see Newman and van der Laan, this volume).

Sample $125-786 \mathrm{~B}-41 \mathrm{R}-2,47-50 \mathrm{~cm}$, is a monogenic intermediate$\mathrm{Ca}$ bronzite andesite breccia with partially altered (montmorillonitebearing) angular clasts, ranging in size from $1 \mathrm{~mm}$ to a few centimeters. Outlines of the clasts are very poorly defined and most of them show a glassy rim due to quenching. The matrix of the breccia is also made up of comparatively fresh glass. Clasts are not connected and no preferred orientation can be discerned. This rock probably resulted from explosion within a subaerial lava flow entering the sea or from direct emplacement in shallow water.

Samples 125-786B-39R-2, 54-56 cm, and -39R-2, 58-62 cm, are pyroclastic andesite deposits. They are made up of angular to subrounded centimeter-sized fragments of dark vacuolar andesite devoid of glassy rims and smaller clasts of light-colored andesite with glassy rims. The cement is a fractured glass with some glomerocrysts. Palagonite and pyrophyllite are present as a glass alteration products. This rock is a pyroclastic breccia which incorporated fragments of previous andesitic flows during explosion or transportation. A shallow-water environment or a transition from a subaerial into a subaqueous environment is suggested by the development of palagonite.

Palagonite is also abundant in Sample 125-786B-34R-1, 113-117 $\mathrm{cm}$. This rock is a fine- to coarse-grained bedded tuff, probably of rhyolitic composition, with eutaxitic texture. Some layers are affected by microfolds caused by "hot" deformation, perhaps during gas escape. Degassing pipes have been observed locally in Sections 125-786B-41R-3 and -22R-3 (Fig. 5). Angular fragments of welded tuff with a planar lamination, rounded clasts of microlitic andesites with glassy rims, and many isolated crystal fragments are also found in some beds. The texture of this rock suggests emplacement in a subaerial environment as an ash-flow or air-fall deposit. However, the occurrence of palagonite may indicate emplacement in shallow water. Subaqueous welded pyroclastic flow tuffs have been reported from many places in the world (see Yamada, 1984, for references).

In contrast to the previous sample, Sample 125-786B-34R-1, $31-35 \mathrm{~cm}$, is weakly devitrified. It consists of millimeter to centimeter-sized fragments of glass and of vesicular rhyolite enclosed in a glassy matrix. Vesicles are flattened, suggesting deformation during either transportation or compaction.

Sample 125-786B-33R-1, 111-115 cm, is again different from both of the previous two samples, as it has a very fine-grained, homogeneous texture. It consists of an accumulation of very fine particles of unaltered glass with some subangular, broken phenocrysts. This rock could represent a rather distal air-fall tuff.

Cores 125-786B-22R and -21R show a spectacular succession of andesitic to rhyolitic flows and tuffs (Fig. 5). The rocks exhibit various structures related mostly to plastic ("hot") or more brittle deformation such as open-to-isoclinal folding of flow-banding, crossed and 
wavy laminations, brecciation, and microfaulting. Some of these structures are commonly encountered in surge deposits and at the base of ignimbrites.

Samples 125-786B-22R-3, 78-82 cm, and -22R-3, 103-106 cm, are bedded tuffs composed of flattened pumice fragments. Bedding is outlined in places by hematite grain concentrations.

Sample $125-786 \mathrm{~B}-22 \mathrm{R}-2,3-8 \mathrm{~cm}$, is an autobrecciated, banded rhyolite. Glass fragments are elongated, locally folded, and cemented by fresh glass. Samples 125-786B-22R-1, 116-121 cm; -22R-1, $110-113 \mathrm{~cm}$; $-22 \mathrm{R}-1,60-63 \mathrm{~cm}$; and $-22 \mathrm{R}-1,49-53 \mathrm{~cm}$, are very fine-grained tuffs similar to the tuff in the previously described Sample 125-786B-33R-1, 111-115 cm. Glassy, flow-banded, intermediate-Ca bronzite andesite flows are identified in intervals 125 $786 \mathrm{~B}-31 \mathrm{R}-1,115-118 \mathrm{~cm}$, and $101-104 \mathrm{~cm}$. Fresh glass and only rare devitrification spherulites have been observed. Sample 125-786B$21 \mathrm{R}-1,54-58 \mathrm{~cm}$, is a bedded rhyolitic tuff consisting of angular, millimeter-sized fragments of crystals and nonflattened yellow glass enclosed in a matrix of very fine particles of montmorillonite-bearing glass. Glass clasts in some beds are matrix-supported. This rock could have formed by quenching of lava entering water or as the result of subaqueous volcanism. The upper part of the sample is reddened, indicating either oxidation due to subsequent heating of the deposit by superposed volcanic products or alteration in paleosols.

Sample $125-786 \mathrm{~B}-21 \mathrm{R}, 26-30 \mathrm{~cm}$, is a slightly brecciated andesite flow.

Near the top of the hole, Sample 125-786B-3R-1, 94-97 cm, is a pyroclastic, monogenic breccia with angular clasts of intermediate-Ca bronzite andesite showing fluidal textures. The cement consists of glass with zones of microlitic texture.

In conclusion, the study of the pyroclastic facies clearly demonstrates that the Bonin forearc basement drilled at Site 786 consists partially of volcanic products emplaced by explosive volcanism, above the PCL. This implies deposition in relatively shallow water or subaerial environments. The pyroclastic facies are absent in the basal part of the hole where nonexplosive hydroclastic facies are abundant (hyaloclastite, pillow breccia) (Fig. 6).

\section{SUMMARY OF STRUCTURAL STUDIES AT SITE 786}

As reported by the Shipboard Scientific Party (1990), cores from Hole 786B show some spectacular structural features (Fig. 2). These include (1) a variety of possible primary igneous flow features, such as steep apparent flow-banding dips $\left(60^{\circ}\right.$ to $\left.70^{\circ}\right)$ and foliation of tuffs and contacts between flows or tuffs; (2) slickensided fault planes with predominant dip-slip striations (movement criteria when present always indicate normal faulting); (3) a ductile shear zone in Core $125-786 \mathrm{~B}-63 \mathrm{R}$; (4) numerous cataclastic zones (fault gouges) and the occurrence of small, slickensided pieces of generally massive rocks; and (5) intense brecciation related to hydrothermal circulation at the base of the hole.

As noted in the previous section, the occurrence of volcanic breccias interbedded with the volcanic products in Hole 786B suggests that the volcanic basement has undergone faulting during the Eocene. This means that some of the faults present in the cores may be early features and not necessarily post-Eocene faults.

Cores from Hole 786A also show clear evidence of normal faulting, especially in the upper part of the hole (Cores 125-786A-1H and $-2 \mathrm{H}$, late Pliocene) (Figs. 7 and 8 ) and at the bottom of the hole where a fault cross-cuts a volcanic pebble (Section 125-786A-11X-4, 100 $\mathrm{cm}$ ). This fault, dipping at $45^{\circ}$, marks the tectonic boundary between middle Eocene nannofossil marls containing numerous volcanic pebbles, and late Eocene marls devoid of volcanic pebbles.

All these features clearly indicate that the forearc basement high has undergone active tectonism, since the initial phase of construction of the volcanic basement in the Eocene. Deformation occurred recently as shown by normal faults cutting very recent sediments of late Pliocene age in the upper section of Hole 786A.

\section{DISCUSSION}

Figure 9 is a synthesis of the structural and lithostratigraphical data obtained at Site 786. This speculative model for the geometry of the upper part of the forearc basement in the drilled area is based primarily on the location and sense of movement of the main fault zones present in the cores, and secondly on the nature of the main stratigraphic layers deduced from shipboard analysis and from this study.

We will now discuss a general scenario for the constructional history of the basement.

As noted by Fisher (1984), volcanic products deposited above the PCL are characterized by the predominance of explosive debris. Nonexplosive hydroclastic debris flows and pillowed and massive flows are dominant in volcanic products emplaced below the PCL.

During the constructional history of an island volcano evolving from submarine to subaerial conditions, two main stages can be expected. Stage A develops below PCL and is characterized by predominant massive and pillowed lavas and related hydroclastites. Stage B develops above PCL, first under shallow water, then under terrestrial conditions as the vents become subaerial (Fisher, 1984). Abundant volcanic debris may be transported by sediment gravity flows along unstable slopes in proximal to very distal parts of the edifice. Numerous epiclastic layers will be interbedded with magmatic products if the area is subjected to renewed tectonic activity or to repeated volcanic pulses with migration of active volcanic centers (Karig and Moore, 1975; Carey and Sigurdsson, 1984). Either massive, hydroclastic, pyroclastic, or epiclastic rocks can be reworked depending on the spacing and timing of the tectonic events.

Petrographic analysis of the different components of polygenic epiclastic breccias may help in determining the depositional environment of some volcanic products. The presence of strongly altered, oxidized, rounded clasts of microlitic lavas (andesite, dacite, etc.) strongly suggests evolution under terrestrial conditions with subaerial weathering prior to the deposition within the breccias. Other criteria such as the presence of angular fragments of welded tuffs within epiclastic breccias also indicates terrestrial or very shallow water sources. Unfortunately, as such clasts may be transported and then deposited at depth by gravity currents, these features cannot be used to determine the exact depth of deposition or the exact distance from the emergent areas. Thus, other criteria are needed. For example, it is clear that the presence of in-situ pyroclastic products interbedded with epiclastic breccias indicates emplacement under subaerial conditions or under shallow water (around $500 \mathrm{~m}$ or less).

Another important criterion for discriminating between subaerial and subaqueous emplacement is the amount of alteration of glass and the absence or occurrence of palagonite. Palagonite develops quickly on glass emplaced in submarine environments and the total absence of palagonite in glass-rich rocks drilled along rather long sections of Hole $786 \mathrm{~B}$ is a good indicator of a subaerial environment. This can be observed in Cores 125-786B-21R and 125-786B-22R where effusive and pyroclastic, glass-rich facies contain extremely fresh glass.

The results of the analysis reported here in conjunction with the $\mathrm{K}-\mathrm{Ar}$ age dates reported by Mitchell et al. (this volume), allow us to propose the following constructional history for the volcanic edifice drilled at Hole 786B. This history shows some similarities with the two-stage model proposed by Fisher (1984).

1. The base of the hole is characterized by numerous dikes, pervasive hydraulic fracturing and related mineralization (stockwork), and albite-chlorite metamorphism (830-760 mbsf). These features confirm that the rocks from this part of the hole represent the core of a volcanic edifice.

2. The massive and pillowed lava flows with hyaloclastite and pillow breccias (760-650 mbsf) have been emplaced below the PCL. Episodes of tectonism occurring during lava emplacement were probably responsible for the deposition of thick beds of hyaloclastite breccias and sandstones found between 730 and $720 \mathrm{mbsf}$. Deposition 
125-786B-21R-1

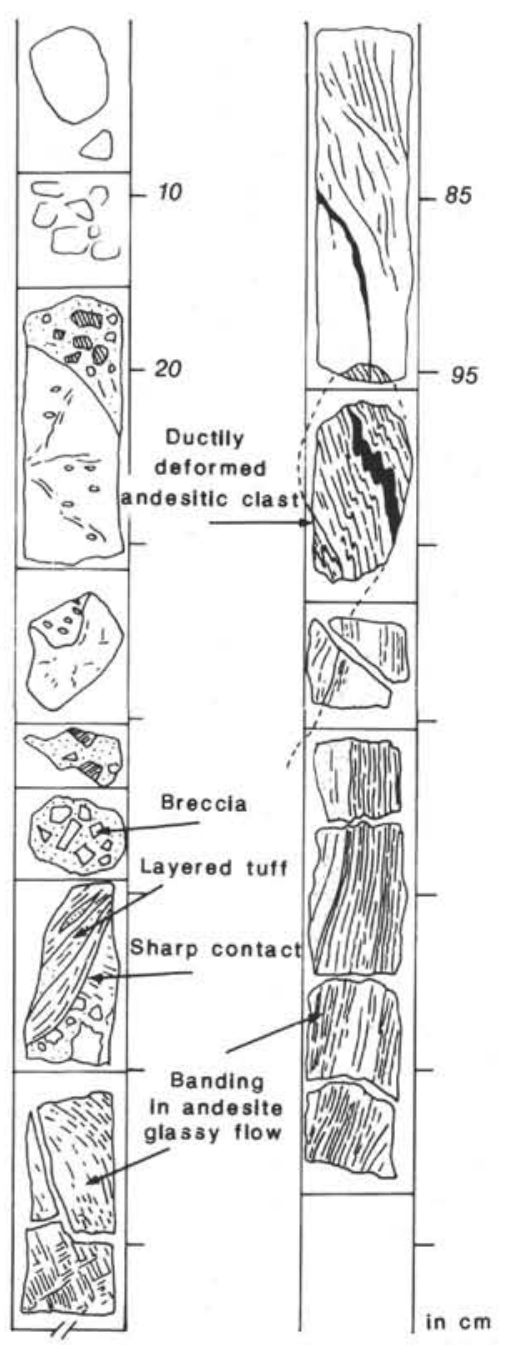

$125-786 B-22 R-1$

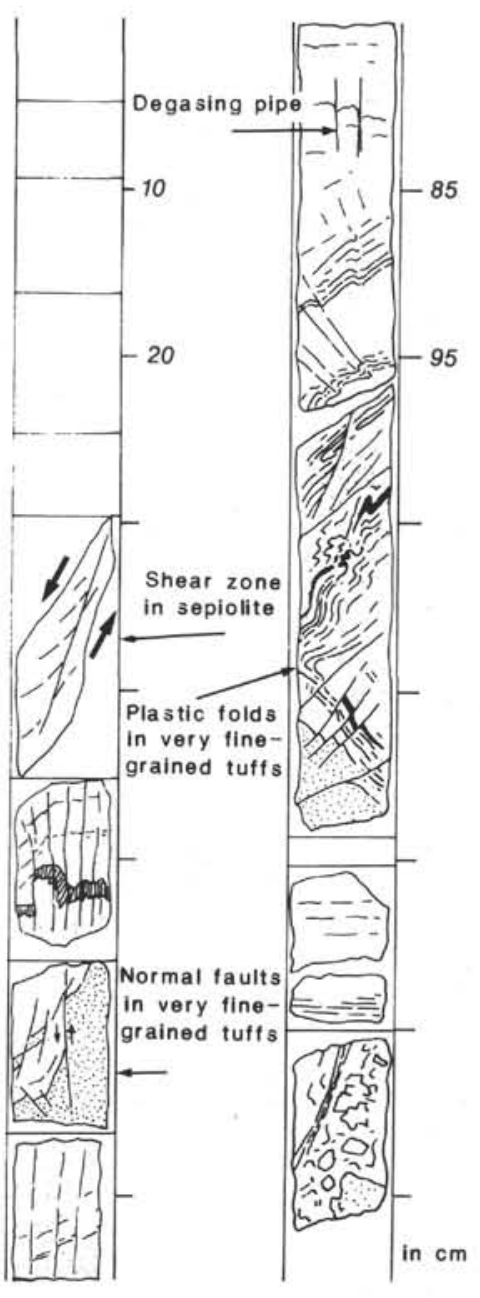

$125-786 B-22 R-2$

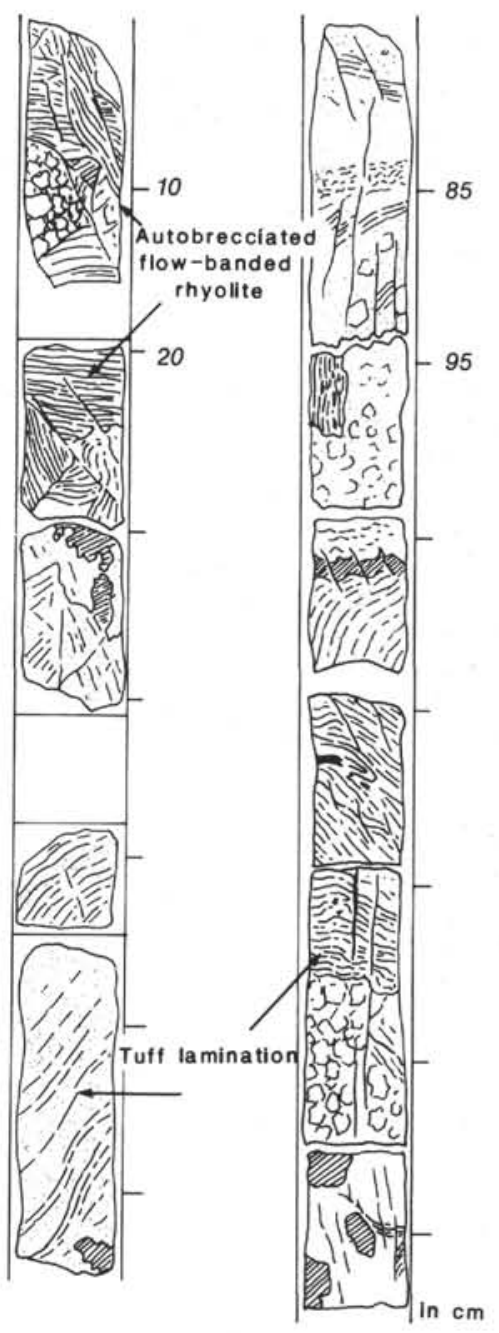

Figure 5. Line drawings from visual descriptions showing the main volcanic and sedimentary structures of Sections $125-786 \mathrm{~B}-21 \mathrm{R}-1,-22 \mathrm{R}-1,-22 \mathrm{R}-2$, $-22 \mathrm{R}-3$, and $-41 \mathrm{R}-3$.

of the polygenic pillow breccias ( 685 to $660 \mathrm{mbsf}$ ) was also probably related to another major tectonic event contemporaneous with the cessation of pillow emplacement.

3. Tectonic events may have also caused fragmentation and movement of debris in more distal parts of the edifice, leading to the emplacement of polymict breccias. Some of the clasts from these deposits (oxidized andesites, tuffs) may have been derived from emergent volcanic edifices.

4. The interval from 575 to $370 \mathrm{mbsf}$ can be described as a succession of dominant lava flows of various composition (boninite, bronzite andesite, andesite, dacite, and rhyolite) with minor thin epiclastic and pyroclastic layers. It should be noted that pillow structures are very rare or absent in this interval. Analysis of epiclastic interbeds reveals that the sources of clastic material become more diverse, with increasing proportions of clasts of altered lavas and subaerial to shallow-water explosive products (pumice, tuffs). The occurrence of few pyroclastic intervals confirms that at this time, the volcanic edifice was above PCL and occasionally very close to sea level. This interpretation is also supported by the absence of palagonite in some glass-rich rocks. The presence of volcanic sandstones with sedimentary structures typical of highenergy environments (Core 125-786B-27R) is indicative of a local shoreline environment.

5. Rocks drilled from 370 to 345 mbsf composed mainly of andesitic to rhyolitic compositions, are mostly clastic (mainly pyroclastic) and massively (flow) structured. It is clear that these rocks have been emplaced above the PCL. Moreover, as shown by thin-section analysis, evidence for renewed volcanic explosions and a lack of glass alteration strongly suggest deposition in very shallow water or occasional subaerial environment. An andesitic flow unit (345-320 mbsf) overlies the previous andesitic-rhyolitic products.

6. A major change in the evolution of the edifice is then marked by the deposition of the monomict and polymict breccias (320-220 mbsf). Clasts of various origins (subaerial and subaqueous volcanic products) are reworked within the breccia.

7. The last volcanic products emplaced over these polymict breccias are intermediate-Ca bronzite andesite flows. Emplacement above the PCL is suggested by the presence of pyroclastic breccias with fresh glass. 
$125-786 \mathrm{~B}-22 \mathrm{R}-3$

$125-786 B-41 R-3$
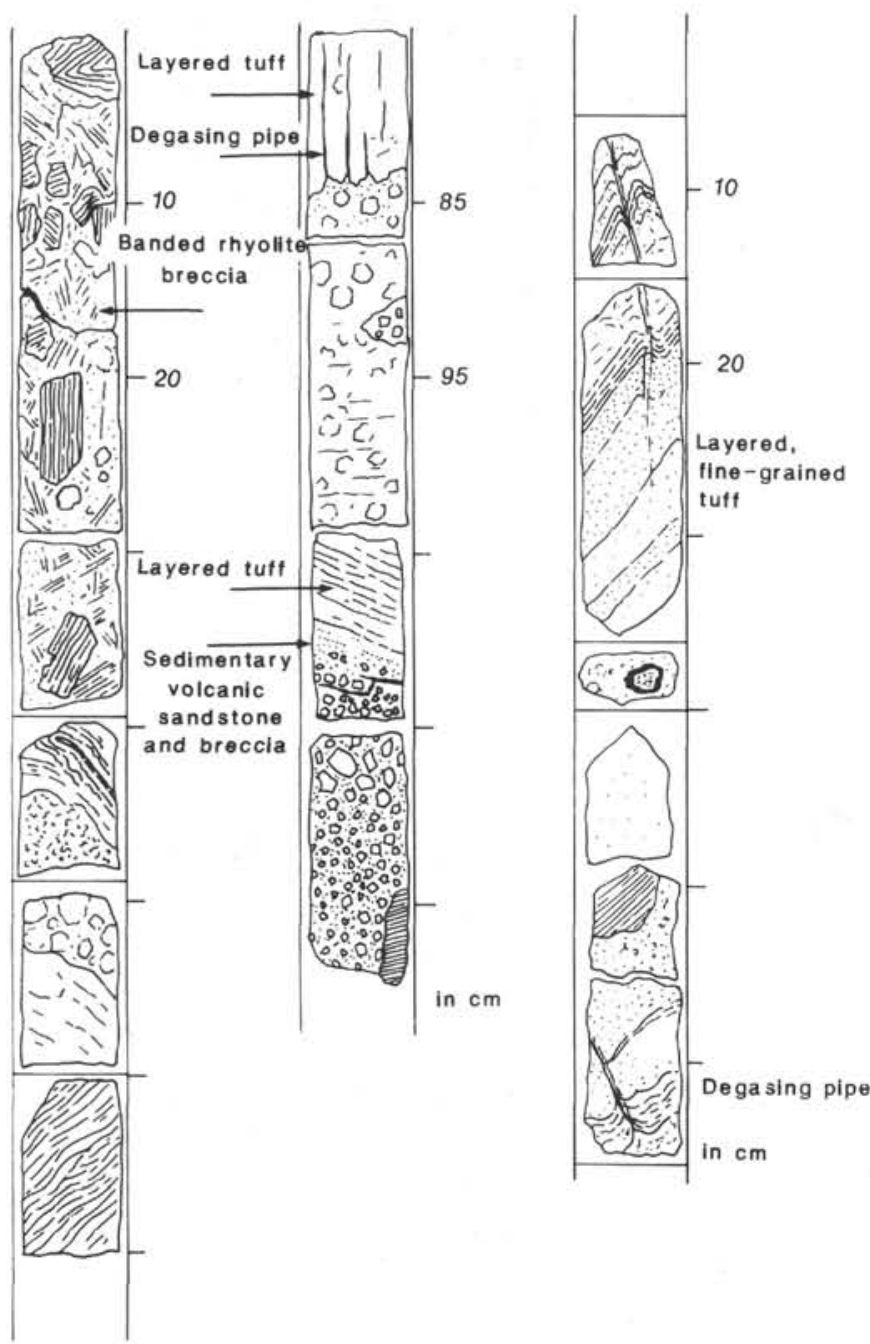

Figure 5 (continued).

\section{CONCLUSIONS}

The two main results of this study can be summarized as follows:

1. The forearc basement high drilled at Site 786 at a depth of more than $3000 \mathrm{~m}$, represents a volcanic edifice, predominantly of Eocene age (also with dikes of Oligocene and possibly Miocene age - see Mitchell et al., this volume) which was formed firstly under the PCL ("pressure compensation level"), then above the PCL with periods of subaerial volcanism. This implies necessarily that the forearc basement has undergone significant subsidence ( 0 to more than $3000 \mathrm{~m}$ depth) since the upper Eocene or lower Oligocene.

2. The Eocene basement and its Tertiary sedimentary cover are cross-cut by numerous normal faults and shear zones indicating significant postdepositional tectonism. In the basement, most of the initially subhorizontal, sedimentary bedding and flow-layering, are now dipping at high angles $\left(40^{\circ}-70^{\circ}\right)$.

Most of the normal faults observed within the basement section (Hole 786B) or within the sedimentary section (Hole 786A) are probably related to the extensional tectonics accompanying the forearc subsidence, and possibly may be related to the Oligocene rifting event involved in the formation of the Bonin Trough. Many comparable tectonic features, but at a larger scale, can also be observed on the interpreted seismic section (Fig. 10).

This seismic line shows that the basement in this area is affected by important, low-angle faults downdropped to the east. Site 786 is located close to a major normal fault with a total offset which may of the order of a few hundred meters. Finally, these observations confirm previous results and interpretations. Evidence for recent subsidence of a significant portion of the Izu-Bonin outer forearc south of the drilled area has been reported by Ishii (1985). The Ogasawara Seamount, now culminating at $1050 \mathrm{~m}$ shows a flat erosion surface and is covered by rounded pebbles of igneous rocks interpreted to be the result of wave erosion. Paleontological data suggest that the subsidence of this "paleoland" started in the early Pliocene. In contrast, the emergent Ogasawara islands (e.g., Chichijima and Hahajima) have not experienced subsidence on this scale.

Strong evidence for forearc subsidence has also been reported from DSDP holes in the Mariana area, especially at Site 460 where an Eocene to Oligocene sequence of calcareous sediments occurs at $6500 \mathrm{~m}$ (Shipboard Scientific Party, Leg 60, Site 460; Hussong and Uyeda, 1981). Predominant normal small-scale faulting has been also reported from holes located near the trench axis (Blanchet, 1980).

In summary, petrological analysis of volcaniclastic rocks and structural studies indicate subsidence of the forearc basement high following the period of igneous construction. It is possible that the upper main breccia interval in Hole 786B marks of the first stages of this subsidence in the uppermost Eocene. According to the curve calculated from Hole $786 \mathrm{~A}$ data, the sedimentation rates increased significantly at $15 \mathrm{Ma}$ and $5 \mathrm{Ma}$. Lower Miocene sediments are missing and a hiatus with a duration of approximately $7 \mathrm{~m} . \mathrm{y}$. is present between the upper Oligocene and the middle Miocene. Increase in the sedimentation rate, as well as the presence of the hiatus, can be correlated with tectonic crises and drastic changes in the regional stress field. It is therefore possible to propose that subsidence of the forearc basement occurred during at least four successive events: (1) during the late Eocene, immediately after, or during the end of the volcanic construction; (2) possibly in the middle Oligocene during the initiation of rifting and the formation of the Bonin Trough; (3) sometime during the early-middle Miocene (27 to $15 \mathrm{Ma}$ ); and (4) around $5 \mathrm{Ma}$, at the Miocene to Pliocene boundary.

These periods of probable subsidence are contemporaneous with major geodynamic events in the West Pacific region: opening of the Parece Vela and Shikoku basins dated at 30-28 Ma and $25 \mathrm{Ma}$, respectively (Mrozowski and Hayes, 1979; Hussong and Uyeda, 1981; Chamot-Rooke et al., 1987; Jolivet et al., 1989), and opening of the Mariana trough dated at 8-5 Ma (Hussong and Uyeda, 1981, Stern et al., 1984).

\section{ACKNOWLEDGMENTS}

Floyd McCoy was an onboard source of inspiration for this study. This work was supported by INSU-ODP France-Océanoscope Grants. Some analytical expenses have been defrayed by Australian Research Council Grant A39030242 to R.J.A.. We thank Mike Marlow and Jean-Pierre Réhault for their help in the interpretation of the multichannel seismic line. We all recognize the efforts of Patty Fryer, Julian Pearce, Laura Stokking, and other shipboard scientists, marine technicians, and the crew of the JOIDES Resolution to the success of drilling efforts at Site 786. I. Gibson and S. Umino provided patient, detailed, and constructive reviews of an initial version of the manuscript.

\section{REFERENCES}

Berthé, D., Choukroune, P., and Jegouzo, P., 1979. Orthogneiss, mylonite and non-coaxial deformation of granites: the example of the South Armorican Shear Zone. J. Struct., 1:31-42. 


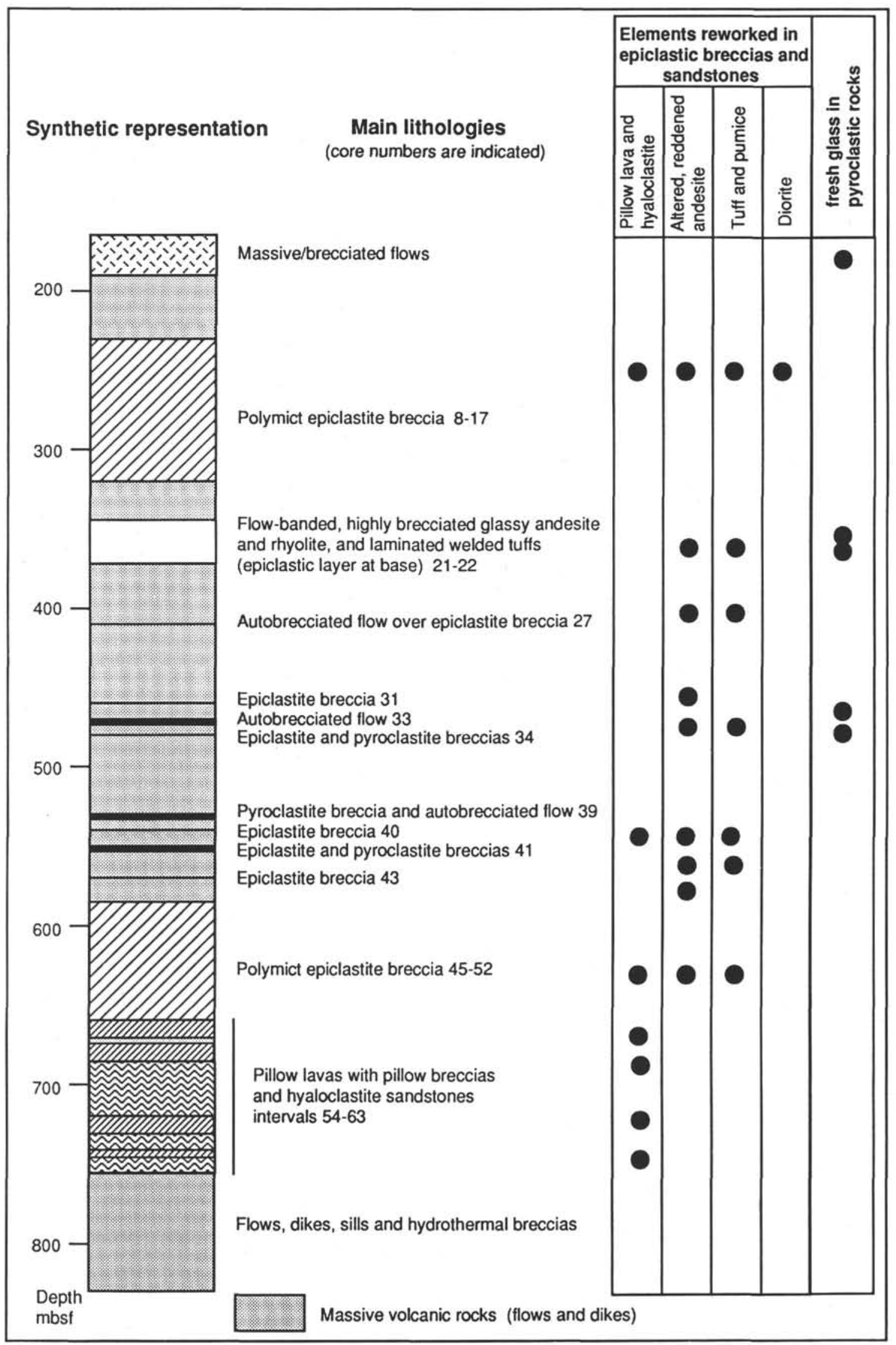

Figure 6. Synthetic log of a Hole 786B section and simplified lithological table based on the results of this study. 
Blanchet, R., 1980. Tectonique sur la marge active des Mariannes, dans le Pacifique occidental. Bull. Soc. Geol. Fr., Suppl., 5:182-183.

Carey, S., and Sigurdsson, H., 1984. A model of volcanogenic sedimentation in marginal basins. In Kokelaar, B. P., and Howells, M. F. (Eds.), Marginal Basin Geology: Volcanic and Associated Sedimentary and Tectonic Processes in Modern and Ancient Marginal Basins. Geol. Soc. Spec. Publ. London, 16:37-58.

Cas, R.A.F., and Wright, J. V., 1987. Volcanic Successions: Modern and Ancient: a Geological Approach to Processes, Products and Successions: London (Allen and Unwin).

Chamot-Rooke, N., Renard, V., and Le Pichon, X., 1987. Magnetic anomalies in the Shikoku Basin: a new interpretation. Earth Planet. Sci. Lett., 83:214-223.

Fisher, R. V., 1984. Submarine volcaniclastic rocks. In Kokelaar, B. P., and Howells, M. F. (Eds.), Marginal Basin Geology: Volcanic and Associated Sedimentary and Tectonic Processes in Modern and Ancient Marginal Basins. Geol. Soc. Spec. Publ. London, 16:5-28.

Fisher, R. V., and Schminke, H.-U., 1984. Pyroclastic Rocks: Heidelberg (Springer-Verlag).

Honnorez J., and Kirst, P., 1975. Submarine basaltic volcanism: morphometric parameters for discriminating hyaloclastites from hyalotuffs. Bull. Volcanol., 39:1-25.

Hussong, D. M., and Uyeda, S., 1982. Tectonic processes and the history of the Mariana arc: a synthesis of the results of DSDP, Leg 60 In Hussong, D. M., Uyeda, S., et al., Init. Repts. DSDP, 60: Washington (U.S. Govt. Printing Office), 909-929.

Ishii, T., 1985. Dredged samples from the Ogasawara fore-arc seamount or "Ogasawara Paleoland"-fore-arc ophiolite. In Nasu, N., Kobayashi, K., Kushiro, I., Kagami, H. (Ed.), Formation of Active Ocean Margins: Tokyo (Terra Sci. Publ.), 307-342.

Jolivet, L., Huchon, P., and Rangin, C., 1989. Tectonic setting of Western Pacific marginal basins. Tectonophysics, 160:23-47.

Karig, D. E., and Moore, G. F., 1975. Tectonically controlled sedimentation in marginal basins. Earth Planet. Sci. Lett., 26:233-238.

Mrozowski, C. L., and Hayes, D. E., 1979. The evolution of the Parece Vela Basin, eastern Philippine Sea. Earth Planet. Sci. Lett., 46:49-67.

Mrozowski, C. L., Hayes, D. E., and Taylor, B., 1982. Multichannel seismic reflection surveys of Leg 60 sites, DSDP project. In Hussong, D. M., Uyeda, S., et al., Init. Repts. DSDP, 60: Washington (U.S. Govt. Printing Office), 57-71.

Sheridan, M. F., 1979. Emplacement of pyroclastic flows: a review. In Chapin, C. E., and Elston, W. E. (Eds.), Ash-Flow Tuffs. Spec. Pap.-Geol. Soc. Am., 180:125-134.

Shipboard Scientific Party, 1982. Site 460. In Hussong, D. M., Uyeda, S., et al., Init. Repts. DSDP, 60: Washington (U.S. Govt. Printing Office), 371-397.

1990. Site 786. In Fryer, P., Pearce, J. A., Stokking, L. B., et al., Proc. ODP, Init. Repts., 125: College Station, TX (Ocean Drilling Program), 313-363.

Sparks, R.S.J., and Wright, J. V., 1979. Welded air-fall tuffs. In Chapin, C. E., and Elston, W. E. (Eds.), Ash-Flow Tuffs. Spec. Pap.-Geol. Soc. Am., 180:155-166.

Stern, R. J., Smoot, N. C., and Rubin, M., 1984. Unzipping of the volcano arc, Japan. Tectonophysics, 102:153-174.

Umino, S., 1985. Volcanic geology of Chichijima, the Bonin Islands (Ogasawara Islands). Chishitsugaku Zasshi, 91:505-523.

, 1986. Geological and petrological study of boninites and related rocks from Chichijima, Bonin Islands [Ph.D. thesis]. Univ. of Tokyo.

Yamada, E., Subaqueous pyroclastic flows: their development and their deposits, 1984. In Kokelaar, B. P., and Howells, M. F. (Eds.), Marginal Basin Geology: Volcanic and Associated Sedimentary and Tectonic Processes in Modern and Ancient Marginal Basins. Spec. Publ.-Geol. Soc. Am., 16:29-36.

Date of initial receipt: 3 October 1990

Date of acceptance: 29 July 1991

Ms 125B-177
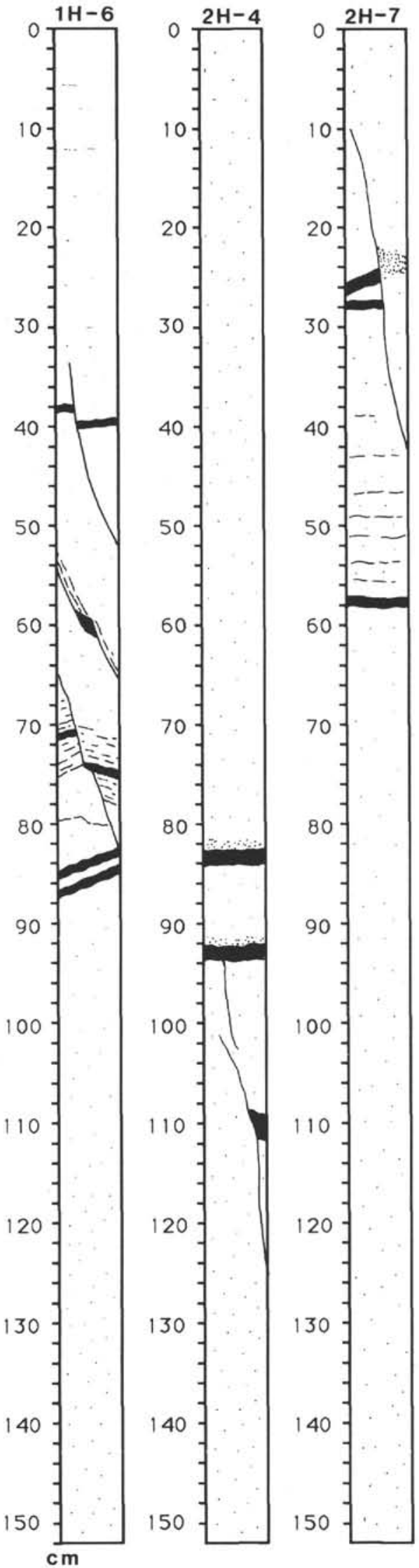

Figure 7. Normal faults offsetting ash layers interbedded with marls and clays in the upper part of Hole 786A (Sections 125-786A-1H-6, -2H-4, and -2H-7). 


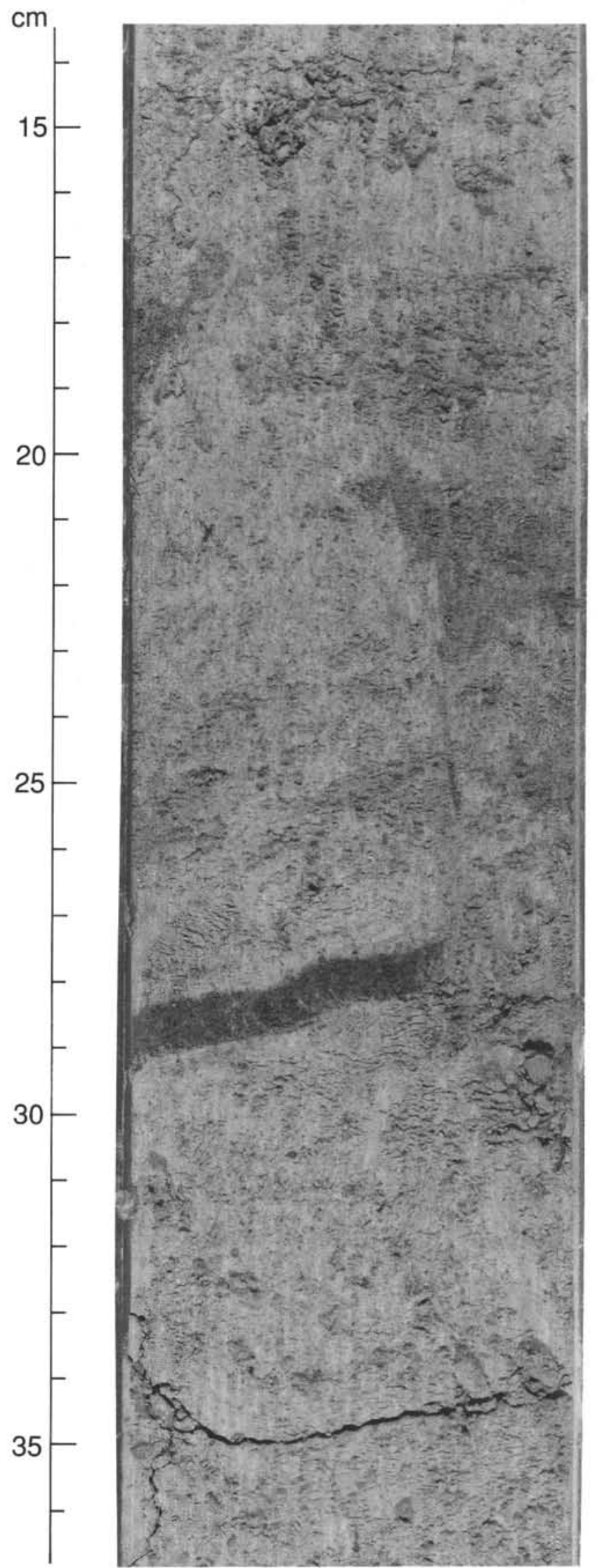

Figure 8. Detailed photograph of a fault that cross-cuts an ash layer in interval 125-786A$2 \mathrm{H}-7,28-30 \mathrm{~cm}$. 


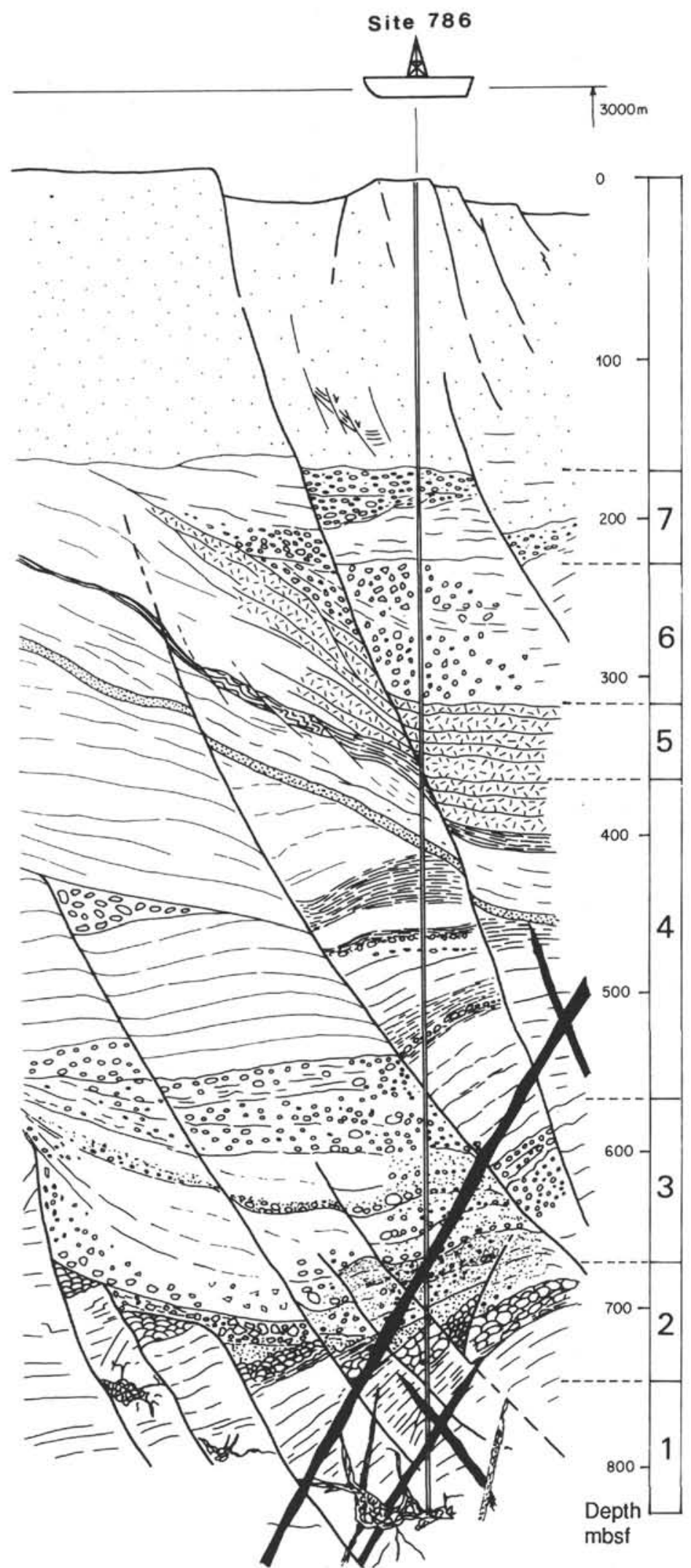

Figure 9. Speculative model of the general structure of the volcanic basement in the vicinity of Site 786. This model takes into account the exact lithology of the drilled intervals and the exact location of the fault zones. Most of the fault surfaces are assumed to be dipping to the east, as suggested by fault geometry that was deduced from seismic profiles (see Fig. 10). Numbers in the righthand column refer to the lithological subdivisions described in the text. 


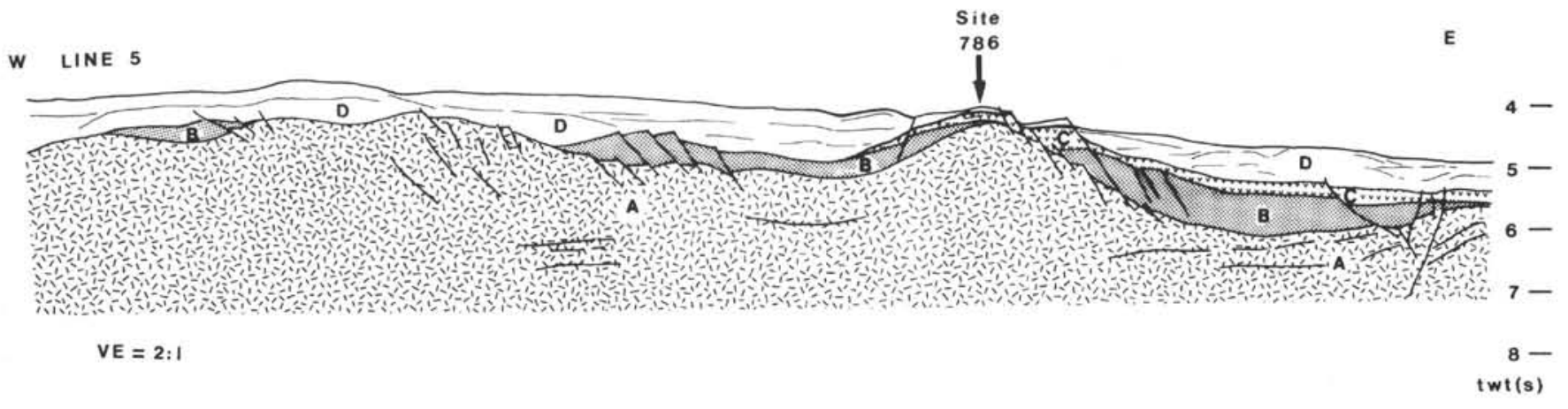

Figure 10. Interpretation of MCS line 5 (see location in Fig. 1) run by B. Taylor and processed by M. Marlow. The acoustic basement (Unit A) probably consists of thick volcanic formations and might represent either the upper part of old oceanic crust or older forearc basement. Unit B consists of a series of different lenses that overlie the previous unit. This unit might correspond to thick volcanic and volcaniclastic (detrital) formations that were emplaced on the flanks of volcanoes. These formations were affected by numerous normal faults, dipping at $40^{\circ}-50^{\circ}$ to the east. Unit C consists of a set of strong reflectors overlying both Units $\mathrm{A}$ and B. The base of this unit can be correlated with the unit of boninitic pillows and related hyaloclastite breccias present from 660 to 750 mbsf in Hole $786 \mathrm{~B}$, which is characterized by good recovery. Unit D resembles the more classical seismic signature of sediments, such as vitric and nannofossils marls, that are classically encountered in the forearc domain and were drilled in Hole 786A. VE = vertical exaggeration; twt ( $s$ = two-way traveltime (seconds). 